\section{JORNADES D'EDUCACIÓ PER LA PAU}

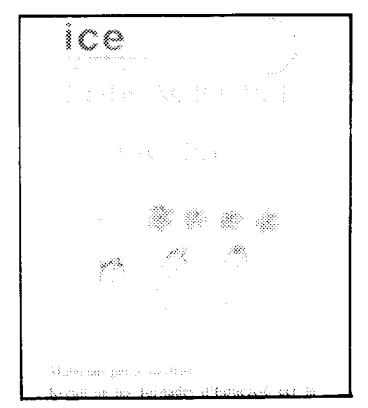

Aquestes Jornades, celebrades a la Divisió dels Centres Universitaris del Camp de Tarragona els dies 11,12 i 13 del passat mes de novembre, van ser organitzades pel Seminari d'Educació per la Pau del Tarragonès. Obertes a tothom, pretenien ser un element més d'ajut per als educadors i educadores, en general, en la difícil tasca de fomentar valors de cooperació, respecte i solidaritat entre els infants i els joves.

Es van iniciar amb una conferència a càrrec d'Octavi Fullat, president del Consell Escolar de Catalunya. En els dos dies següents vam gaudir de les exposicions encertades de tot un seguit de personatges estretament vinculats al tema de la Pau, així com als valors i conceptes que aquesta implica i representa. Vam poder escoltar Carme Romia, professora de la Universitat Internacional de la Pau, Miquel Martí, coordinador estatal de les escoles associades de la UNESCO, Dolors Reig, coordinadora pedagògica del projecte LINGUAPAX, i Vicens Fisas, investigador sobre desarmament i premi Memorial per la Pau Vidal i Llecha. Cadascuna d'aquestes intervencions va anar seguida de col.loquis molt profitosos, on es palesava la inquietud existent sobre els temes tractats.

L'acte de cloenda va ser una taula rodona que, sota el títol “Educar per la Pau», aplegà l'esmentat Vicens Fisas, Assumpta Eixarch, membre de Biaix, centre per la Pau i el Desenvolupament, de Reus, Santiago Camós, president de Justicia i Pau de Tarragona, Ma. Teresa Piquer, inspectora d'Ensenyament i Montserrat Santisteban i Aurora Aubach, ambdues professores de l'Escola de Mestres, aquesta última en qualitat de moderadora.

Convé fer esment especial de l'exposició de material didàctic divers, que restà oberta durant els tres dies de les Jornades, i que va tenir força acceptació.

Els membres delSeminaricelebrem labona acollida que tots aquests actes varen tenir, i agraïm la participació il'interès que se'ns ha mostrat. Recentment hem presentat un dossier, fruit de quatre anys de recopilació i elaboració de material, que inclou també un apartat sobre aquestes Jornades.

\section{EL IV SIMPOSI DE DIDÀCTICA DE LES CIĖNCIES SOCIALS CELEBRAT A GIRONA}

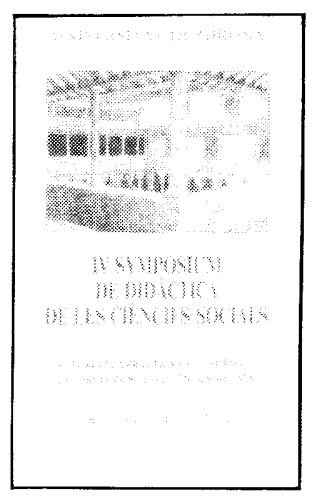

L'Associació Universitària de Professors de Didàctica de les Ciències Socials ha celebrat a Girona el seu IV Simposi, durant els proppassats dies del 8 a l'11 d'abril. En aquesta organització en dugueren el pes, sobretot, les unitats de Didàctica de les Ciències Socials de la Universitat de Girona i de l'Autònoma de Barcelona.

El tema en el qual s'aplegaren el gruix majoritari de professors i professores de Didàctica de les Ciències Socials de les Escoles de Mestres de tot l'Estat va ser "La teoria i la pràctica en la formació del professorat de Ciències Socials". També hi assistiren professors d'altres nivells educatius, preocupats per trobar, en aquesta etapa de canvi curricular, aspectes de millora que puguin incidir directament o indirecta en les classes que imparteixen.

La ternàtica científica, densa de contingut, s'aplegà al voltant de cinc macrosessions organitzades en forma de conferències, impartides per prestigiosos especialistes del món de la psicopedagogia i de la Didàctica de les Ciències Socials. La mecànica de treball, simple però ben travada, va consistir en la impartició de la conferència i en la seva discussió posterior, en grups reduïts, on un moderador, ja predeterminat, efectuava la recopilació sintètica de les intervencions dels participants de cara a formular preguntes al conferenciant, les quals eren respostes per aquest en una altra sessió, on s'aplegava el gran grup. Per tal de fer més operatius aquests grups, l'organització, amb bon criteri, optà per dividir-los en tres àmbits, atenent la nova reformulació de la Reforma, és a dir: Educació Infantil, Primària i Secundària.

El primer dia ocupà la tribuna Cèsar Coll, de l'àrea de Psicologia de l'Educació de la Universitat de Barcelona, el qual parlà sobre «Elements per a l'anàlisi de la pràctica educativa". El seu discurs el basà en la presentació de les hipòtesis de treball de les investigacions que està dirigint. Aquestes tracten de demostrar que els aprenentatges dels alumnes són, en part, les conseqüències del que fan els professors. Això implica que en la formació del professorat cal ajudar els estudiants a reflexionar sobre la seva pràctica, ja que, segons els seus raonaments, aquesta és per norma general, parcial, intuïtiva i poc rigorosa. En aquest mateix estadi indicà que per afavorir 




l'activitat constructiva de l'alumne s'han de considerar els continguts i les activitats que planifica el professor. Tot amb tot, el punt més interessantialhora el més controvertit el significà l'exposició de quins eren els mecanismes d'influència educativa, basant la seva hipòtesi a crear les condicions perquè l'alumne sigui actor de l'aprenentatge i construeixi coneixements, la qual cosa implica la cessió parcial del control del protagonisme del professor a l'alumne per construir coneixements. S'estengué en la teoria de la "bastida" per a la construcció de l'aprenentatge, afirmant que era del tot necessària, i que toti que sembla que no deixa rastre per la seva temporalitat, hi ha indicadors empírics que demostren la seva incidència.

La segona conferència anà a càrrec de Stephen Thornton, professor de la Universitat de Columbia, USA, elqual dissertà sobre "Quins principis porten els professors de Ciències Socials a la classe? “. Indicà que creia que hi havia tres punts clau referents al paper del professor controlador a les Ciències Socials. Un el concretà a saber el que opinaven els mateixos professors; un segon, referit als criteris en què es basaven per ensenyar; i un tercer, quines estratègies docents eren necessàries per impartir les Ciències Socials. Fruit d'aquesta investigació d'impacte en la formació de docents, opinà que s'havia de cimentar més un "ensenyament ecològic", que s'havia d'anar més cap a una docència reflexiva i que s'havia de tornar a plantejar l'intercanvi de professors entre els diferents nivells de l'ensenyament, aspecte en general descuidat.

La tercera conferència la pronuncià el professor londinenc Michael Naish sota el títol de "La Geografia:un mitjà peral'educació. Aconseguir el canvi en el currículum escolar". Inicià el seu discurs amb la necessitat de saber per endavant quintipus de curs interessaria els estudiants, per adaptar-lo a les seves necessitats i per aconseguir un aprenentatge on els propòsits es poguessin complir. Indicà que el lligam entre persones i medi hauria de servir perquè s'interactués en la col.lectivitat quan aquest alumne hi viu. Proposà una Geografia que suggerís problemes $i$ impliqués aspectes econòmico-político-culturals en els temes. Conformà una Geografia per als 16-18 anys on l'alumne aprengués per ell mateix. Finalment aportà una qüestió pràctica de l'aprenentatge per investigació, tot assenyalant els punts positius i negatius que trobava en el seu model. Indicà també l'equilibri d'escales amb què treballava i es defini per un model on els contrastos local, nacional i internacional hi fossin presents.

La quarta sessió anà a càrrec de Maryse Clary, professora francesa de la Universitat d'Aix-Marseille, sota el títol d' "Aprendre a situar. Situar per aprendre". La seva dissertació va girar, bàsicament, entorn de quatre qüestions: què fa el geògraf, amb quina geografia quedar- nos, com fer el món intel.ligible i, d'acord amb tot això, quina formació cal donar als futurs ensenyants. Segons Clary, el geògraf ha d'articular el saber científic i la demanda social, és a dir, ha de donar claus interpretatives per poder analitzar el món a partir de nocions o conceptes i models que situïn des d'una realitat concebuda a una realitat interpretada. Això cal tenir-ho present quant a la formació dels ensenyants, ja que en lloc de fer persones "distribuïdores del saber", cal formar-les perquè siguin capaces de posar els nois i noies en situació d'interrogarse, de "suscitar-los el desig de saber".

La cinquena i darrera sessió la pronuncià la professora Anna Maria Ajello, del Departament de Psicologia del Procés de Desenvolupament i Socialització, adscrita a la Universitat del Estudide Roma "La Sapienza", sota el títol de "L'ensenyament de les Ciències Socials: qüestions teòriques, propostes operatives". Se centrà en tres eixos: quines són les caracteristiques dels conceptes socials en el context educatiu, els fonaments del curriculum i quines han de ser les característiques per articular aquest bagatge en els professors. La seva aportació tractà de temes nous $i$ alhora candents, com la relació entre el llenguatge familiar i el científic dins del camp de les socials, en els termes socials que fan servir els alumnes, en el problema de la comprensió en les CCSS $i$ en l'exploració en les Ciències Naturals, en el saber analògic, etc. En aquestes i en d'altres qüestions aportà models pràctics del treball que s'està efectuant.

Enconjunt, la celebració del IV Simposi ha significat obrir noves pautes de debat per incidir en el fet que el millorament d'acció, de cara a unes Ciències Socials renovades, passa i passarà per una reflexió del perquè es fan les coses d'una determinada manera. A partird'aquesta reflexió-debat, de ben segur que individualment o en grup s'arbitraran solucions per a un millor domini teòric de la disciplina i, sobretot, per a una renovació didàctica adequada a cada nivell i a cada situació.

Antoni Gavaldà Torrents Didàctica de les Ciències Socials 